\title{
Genetic diversity analysis of the Uruguayan Creole cattle breed using microsatellites and mtDNA markers
}

\author{
E. Armstrong ${ }^{1 *}$, A. Iriarte ${ }^{1,3 *}$, A.M. Martínez ${ }^{2}$, M. Feijoo ${ }^{3}$, J.L. Vega-Pla ${ }^{4}$, \\ J.V. Delgado ${ }^{2}$ and A. Postiglioni ${ }^{1}$ \\ ${ }^{1}$ Área Genética, Departamento de Genética y Mejora Animal, \\ Facultad de Veterinaria, Universidad de la República, Montevideo, Uruguay \\ ${ }^{2}$ Departamento de Genética, Facultad de Veterinaria, Universidad de Córdoba, \\ Córdoba, España \\ ${ }^{3}$ Laboratorio de Evolución, Facultad de Ciencias (UDELAR), Montevideo, \\ Uruguay \\ ${ }^{4}$ Laboratorio de Investigación Aplicada, Cría Caballar de las Fuerzas Armadas, \\ Córdoba, España \\ *These authors contributed equally to this study. \\ Corresponding authors: E. Armstrong / A. Iriarte \\ E-mail: eileen.armstrong@gmail.com / airiarteo@gmail.com
}

Genet. Mol. Res. 12 (2): 1119-1131 (2013)

Received July 7, 2012

Accepted October 10, 2012

Published April 10, 2013

DOI http://dx.doi.org/10.4238/2013.April.10.7

\begin{abstract}
The Uruguayan Creole cattle population $(\mathrm{N}=600)$ is located in a native habitat in south-east Uruguay. We analyzed its genetic diversity and compared it to other populations of American Creole cattle. A random sample of 64 animals was genotyped for a set of 17 microsatellite loci, and the D-loop hyper-variable region of mtDNA was sequenced for 28 calves of the same generation. We identified an average of 5.59 alleles per locus, with expected heterozygosities between 0.466 and 0.850 and an expected mean heterozygosity of 0.664 . The polymorphic information content ranged from 0.360 to 0.820 , and the global $F_{\text {IS }}$ index was 0.037 . The D-loop analysis revealed three haplotypes (UY1, UY2 and UY3), belonging to the European
\end{abstract}


matriline group, with a haplotype diversity of 0.532 . The history of the population, changes in the effective population size, bottlenecks, and genetic drift are possible causes of the genetic variability patterns that we detected.

Key words: Creole cattle breeds; Population analysis; Molecular markers

\section{INTRODUCTION}

American Creole cattle descend from Iberian cattle breeds introduced by the Spanish and Portuguese conquerors in the XVth century (Primo, 1992). Their adaptation to different environments allowed the expression of high levels of genetic variability, this being a source of hidden alleles of potential use in breeding programs and thus important to study and preserve (Barrera et al., 2006; De Alba Martínez, 2011). The analysis of nuclear and cytoplasmic markers, such as microsatellites and mitochondrial DNA (mtDNA), is a valuable tool to infer and assess their genetic diversity and relationships with other cattle populations of America, Europe and Africa (Armstrong et al., 2006a; Ginja et al., 2010; Delgado et al., 2012).

Cattle were first introduced in Uruguay at the beginning of the XVIIth century from the central region of South America (currently Northern Argentina and Paraguay), and later on by the Jesuit Missions of Alto Uruguay. The cattle population grew extensively, becoming semi-wild. Late in the XIXth century, the introduction of more selected European breeds caused a decline in the Creole cattle, reducing the huge initial population to small and sparse subpopulations throughout the country (Primo, 1992; Postiglioni et al., 2002).

After 400 years of natural selection, Uruguayan Creole cattle (Bos taurus) are considered adapted to the environment of the country. Even taking into account some degree of genetic introgression from commercial breeds, it is assumed that they have remained mainly in reproductive isolation due to phenotypic and genetic distinctiveness, as they form a separate and consistent population apart from other American Creole cattle and commercial breeds (Rodríguez et al., 2001; Postiglioni et al., 2002; Delgado et al., 2012).

Currently, there is a single population of approximately 600 pure individuals restricted to San Miguel National Park, in the southeast of Uruguay. The foundation stock consisted of 35 Creole cows, bulls and calves brought from different locations around 70 years ago (Arredondo, 1958). The management of the population since then has consisted in limiting the number of breeding males and the periodic culling of a certain number of animals as a way of controlling population size.

Different molecular markers have been analyzed in this population, including a set of 18 microsatellite loci in breeding bulls (Armstrong et al., 2006a), RAPD markers (Rincón et al., 2000), the polymorphic region of the DRB3.2 gene of the major histocompatibility complex (Kelly et al., 2002) and major genes related to milk and beef production (Postiglioni et al., 2002; Rincón et al., 2006; Armstrong et al., 2011).

Highly informative nuclear and cytoplasmic DNA molecular markers would allow the estimation of the levels of within-breed diversity and possible admixture in this Uruguayan Creole population, as well as the elucidation of genetic relationships with reported European and Latin American breeds (Delgado et al., 2012). Analysis of mtDNA sequences and 
eventually of Y chromosome haplotypes would help to understand the heterogeneous genetic composition of Creole cattle, through the detection of both European and African influences. Taurine mitochondrial diversity could be evaluated with two major mitochondrial haplotype clusters as reference, each group being usually named as European consensus (Eucons) and African consensus (Afcons) (Bradley et al., 1996; Ginja et al., 2010). These groups represent the central haplotypes of phylogenetic networks presented so far, where a number of peripheral haplotypes coalesce (Troy et al., 2001; Miretti et al., 2004).

The aim of our study was to determine the genetic diversity and population genetic structure of Uruguayan Creole cattle and their phylogenetic relationships with other Creole populations, using microsatellites and the hypervariable D-loop region of mtDNA. Our study will contribute to the genetic characterization and conservation management strategies of this unique and relict population of Uruguayan Creole cattle.

\section{MATERIAL AND METHODS}

\section{Microsatellite markers}

Genomic DNA was extracted from random blood samples of 64 Uruguayan Creole cattle (Figure 1). The 17 dinucleotide microsatellite loci studied are all included in the list proposed by FAO (1999; Initiative for Domestic Animal Diversity) and/or in the databank of the bovine diversity project "Cattle Diversity Data Base" (www.fao.org/dad-is; www.thearkdb. org).

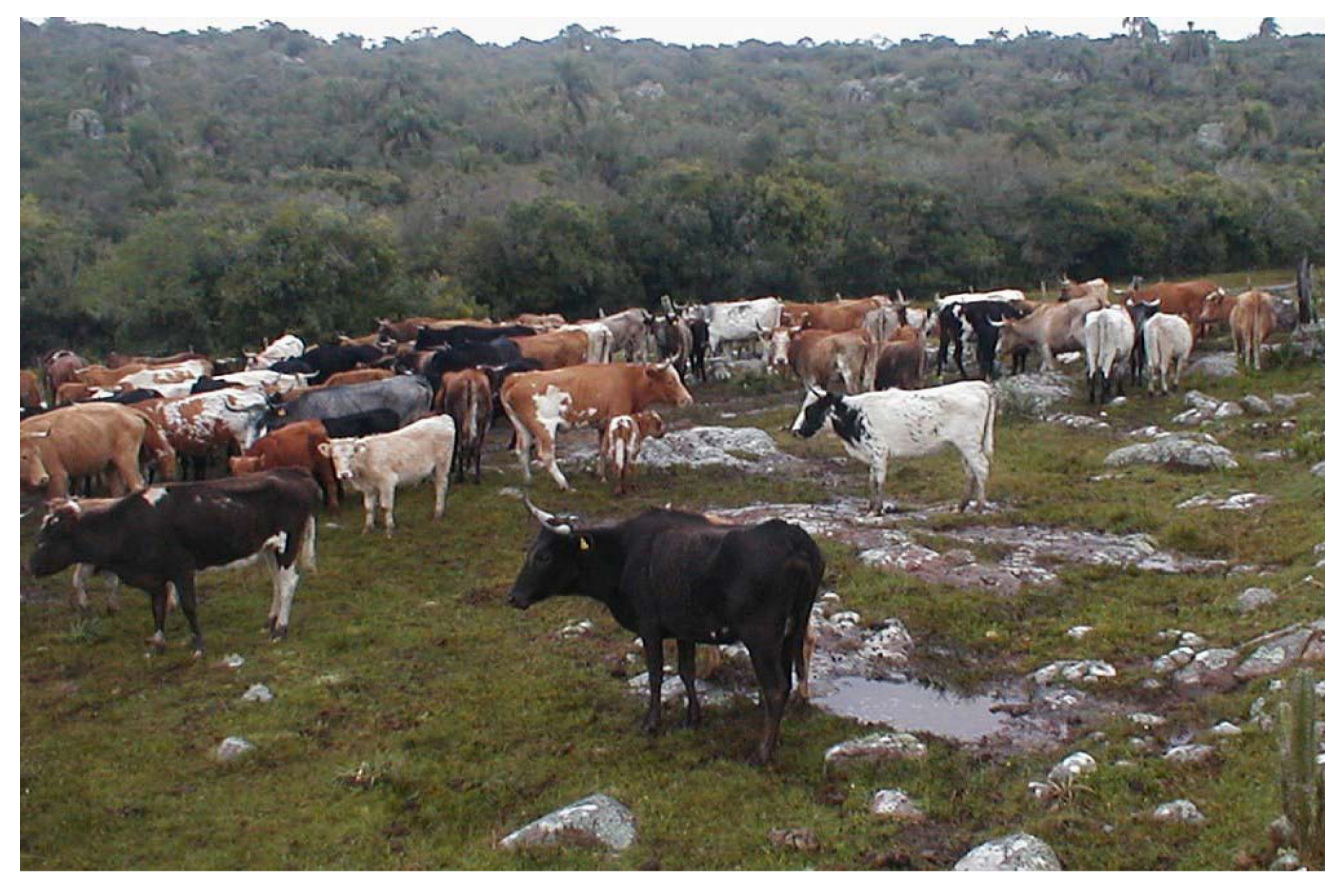

Figure 1. Picture of the Uruguayan Creole cattle herd at San Miguel National Park, Rocha, Uruguay. 
The amplification was performed by polymerase chain reaction (PCR) in three multiplex reactions: multiplex I (BM1314, CSSM66, ILSTS011, INRA37, and ETH10); multiplex II (BM1818, BM2113, BM8125, INRA32, and MM12); and multiplex III (HAUT27, HEL13, HEL9, CSRM60, ILSTS006, INRA63, and TGLA227), as described elsewhere (Armstrong et al., 2006a). The amplified fragments were visualized by electrophoresis on $6 \%$ polyacrylamide gels using an automatic sequencer ABI377XL (Applied Biosystems, Foster City, CA, USA). Genotyping was performed with the GENESCAN ANALYSIS v3.2.1 and the GENOTYPER v2.5 software (Applied Biosystems). Allele size was standardized using reference samples distributed by the International Society of Animal Genetics (ISAG) for comparison tests.

\section{Statistical analysis}

Allelic frequencies were calculated using GENEPOP v3.1c [updated version of GENEPOP v1.2 described in Raymond and Rousset (1995)], as well as the Hardy-Weinberg equilibrium (HWE) exact test. GENETIX v4.02 (Belkhir et al., 1996-2004) was used to calculate the observed $\left(H_{\mathrm{O}}\right)$, expected $\left(H_{\mathrm{E}}\right)$ and unbiased expected heterozygosities and the $F_{\text {IS }}$ statistics. Polymorphic information content (PIC) was calculated according to Botstein et al. (1980). To detect possible effects of past population bottlenecks, three tests based on differences between $H_{\mathrm{O}}$ and $H_{\mathrm{E}}$ under the hypothesis of drift-mutation equilibrium (sign test, standardized differences test and Wilcoxon test) were used for the infinite allele model (IAM) and the stepwise mutation model (SMM). The mode-shift indicator, a descriptor of the allele frequency distribution proposed by Luikart et al. (1998), was also used for this purpose. All these calculations were performed with BOTTLENECK v. 1.2.02 (Cornuet and Luikart, 1996).

\section{Mitochondrial DNA}

Samples for mtDNA analyses were collected from 28 calves from the same generation, randomly chosen from the population of Uruguayan Creole cattle. This method reduces to some extent the probability of sampling individuals matrilineally related to the first degree. DNA was extracted from hair follicles using the Chelex (5\%) method (Walsh et al., 1991) and quantified in a Nanodrop ND-1000 (Thermo Fisher Scientific Inc., Wilmington, DE, USA).

\section{PCR amplification and sequencing}

A fragment of approximately $1 \mathrm{~kb}$ of the mitochondrial D-loop sequence was amplified with forward primer: 5'-TTCCGACCACTCAGCCAATG-3' and reverse primer: 5'-GCATCTTGAGCACCAGCA-3'. The fragment obtained was between positions 15460 and 16480. PCR was performed in a reaction mix containing the following: $200 \mathrm{ng}$ DNA, $10 \mathrm{pM}$ dNTP, $10 \mathrm{pM}$ of each primer, $2.5 \mathrm{U}$ Taq DNA polymerase, and $1.5 \mathrm{mM} \mathrm{MgCl}$. PCR cycling consisted of initial denaturation at $94^{\circ} \mathrm{C}$ for 3 min and 30 cycles at $94^{\circ} \mathrm{C}$ for $60 \mathrm{~s}, 57^{\circ} \mathrm{C}$ for 45 $\mathrm{s}$, and $72^{\circ} \mathrm{C}$ for $60 \mathrm{~s}$, with a final extension at $72^{\circ} \mathrm{C}$ for $4 \mathrm{~min}$. Amplification and sequencing of the 28 amplicons were carried out following the method described by Miretti et al. (2002).

The hypervariable D-loop sequence from animals of other Creole cattle populations of the Americas $(\mathrm{N}=253)$ and sequences belonging to animals from Europe and Africa $(\mathrm{N}=$ 
570) were downloaded from the NCBI database (http://www.ncbi.nlm.nih.gov/), which have been cited in previous studies (Miretti et al., 2004; Ginja et al., 2010) (Table S1).

\section{Statistical analysis}

Sequences were aligned using CLUSTALW (Thompson et al., 1994) and the multiple alignment algorithm of BIOEDIT v7.0.1 (Hall, 1999). Geographical breed structure was estimated with analysis of molecular variance (AMOVA) that computes a Wright's hierarchical F-statistics analogue, $\Phi$-statistics, which incorporates evolutionary distance between haplotypes in addition to frequency data, using ARLEQUIN v3.1 (Excoffier et al., 2005). Pairwise differences were used for AMOVA and groups were defined as geographically and historically distant breeds based on bibliographic criteria: Argentina, Bolivia, Colombia, Brazil, Caribbean, Iberian Peninsula, Africa, and Great Britain. Population pairwise fixation indices were also calculated using ARLEQUIN v3.1.

\section{Phylogenetic analysis}

We used the MODELGENERATOR v0.85 program (Keane et al., 2006) to find the most appropriate model of nucleotide sequence evolution and the gamma shape parameter. Phylogenetic trees were constructed by the neighbor-joining method, included in MEGA 4.0 (Kumar et al., 2008). The maximum likelihood method was used and implemented by means of PHYML v3.0 (Guindon and Gascuel, 2003).

The Hasegawa-Kishino-Yano + gamma + invariant sites $(\mathrm{HKY}+\mathrm{G}+\mathrm{I})$ model (Hasegawa et al., 1985), which incorporates different rates for transitions and transversions, rate variation across sites, and a proportion of invariable sites, was used.

Estimated gamma shape parameter was defined to construct trees in both cases. NETWORK v4.5.1.6 (www.fluxus-engineering.com) was used to construct median-joining networks (Bandelt et al., 1999), connecting the inferred haplotypes present in South America (excluding Brazil) to study the intraspecific phylogenetic pathways of Uruguay's breed haplotypes.

\section{RESULTS}

\section{Microsatellites}

A total of 95 alleles were detected in the sample of the 169 described for the markers used (http://www.marc.usda.gov/genome/cattle/cattle.html). The most polymorphic microsatellite was INRA37 with 10 alleles, while the least polymorphic were BM8125 and INRA63 with 3 alleles (Table 1). The mean number of alleles per locus was 5.59 (Table 2). Genetic diversity indices for each marker are shown in Table 1 and the mean values in Table 2. Almost all markers exhibited heterozygosity levels above 0.50 , as well as high PIC values.

The majority of the loci revealed no significant departures from HWE, excepting three markers. Most $F_{\text {IS }}$ indices were less than 0.10 , as well as the global $F_{\text {IS }}(\mathrm{F}=0.037$ ) (Tables 1 and 2). Bottleneck analysis results are shown in Table 3. 


\section{Table 1. Microsatellite loci analyzed.}

\begin{tabular}{|c|c|c|c|c|c|c|c|c|c|c|c|}
\hline \multicolumn{2}{|c|}{ BM8125 } & \multicolumn{2}{|c|}{ BM1314 } & \multicolumn{2}{|c|}{ BM1818 } & \multicolumn{2}{|c|}{ BM2113 } & \multicolumn{2}{|c|}{ CSSM66 } & \multicolumn{2}{|c|}{ ETH10 } \\
\hline \multicolumn{2}{|c|}{$\mathrm{N}=64$} & \multicolumn{2}{|c|}{$\mathrm{N}=60$} & \multicolumn{2}{|c|}{$\mathrm{N}=55$} & \multicolumn{2}{|c|}{$\mathrm{N}=61$} & \multicolumn{2}{|c|}{$\mathrm{N}=59$} & \multicolumn{2}{|c|}{$\mathrm{N}=59$} \\
\hline Allele & Freq. & Allele & Freq. & Allele & Freq. & Allele & Freq. & Allele & Freq. & Allele & Freq. \\
\hline 116 & 0.641 & 155 & 0.050 & 260 & 0.364 & 124 & 0.016 & 179 & 0.008 & 213 & 0.127 \\
\hline 122 & 0.352 & 157 & 0.417 & 262 & 0.127 & 126 & 0.328 & 181 & 0.212 & 215 & 0.025 \\
\hline \multirow[t]{6}{*}{124} & 0.008 & 159 & 0.367 & 264 & 0.464 & 128 & 0.016 & 183 & 0.119 & 217 & 0.331 \\
\hline & & 161 & 0.167 & 268 & 0.045 & 132 & 0.008 & 187 & 0.263 & 219 & 0.517 \\
\hline & & & & & & 134 & 0.107 & 189 & 0.153 & & \\
\hline & & & & & & 136 & 0.205 & 193 & 0.008 & & \\
\hline & & & & & & 138 & 0.238 & 195 & 0.110 & & \\
\hline & & & & & & 140 & 0.082 & 197 & 0.127 & & \\
\hline$H_{\mathrm{O}}$ & 0.438 & $H_{\mathrm{O}}$ & 0.567 & $H_{\mathrm{O}}$ & 0.618 & $H_{\mathrm{O}}$ & 0.771 & $H_{\mathrm{O}}$ & 0.898 & $H_{\mathrm{O}}$ & 0.627 \\
\hline$H_{\mathrm{E}}$ & 0.466 & $H_{\mathrm{E}}$ & 0.662 & $H_{\mathrm{E}}$ & 0.635 & $H_{\mathrm{E}}$ & 0.775 & $H_{\mathrm{E}}$ & 0.820 & $H_{\mathrm{E}}$ & 0.607 \\
\hline $\mathrm{H}_{\mathrm{E}_{u}}$ & 0.470 & $\mathrm{H}_{\mathrm{E}}^{\mathrm{E}}$ & 0.667 & $\mathrm{H}_{\mathrm{Eu}}^{\mathrm{E}}$ & 0.640 & $\mathrm{H}_{\mathrm{F}_{u}}^{\mathrm{E}}$ & 0.782 & $\mathrm{H}_{\mathrm{Eu}}^{\mathrm{E}}$ & 0.827 & $\mathrm{H}_{\mathrm{Eu}}^{\mathrm{E}}$ & 0.612 \\
\hline PIC & 0.360 & PIC & 0.600 & PIC & 0.570 & PIC & 0.750 & PIC & 0.820 & PIC & 0.540 \\
\hline $\mathrm{P}$ & 0.735 & $\mathrm{P}$ & 0.074 & $\mathrm{P}$ & 0.743 & $\mathrm{P}$ & 0.177 & $\mathrm{P}$ & 0.415 & $\mathrm{P}$ & 0.104 \\
\hline$F_{\text {IS }}$ & 0.069 & $F_{\text {IS }}$ & 0.152 & $F_{\text {IS }}$ & 0.035 & $F_{\text {IS }}$ & 0.015 & $F_{\text {IS }}$ & -0.087 & $F_{\text {IS }}$ & -0.025 \\
\hline \multicolumn{2}{|c|}{ ILSTS011 } & \multicolumn{2}{|c|}{ INRA32 } & \multicolumn{2}{|c|}{ INRA37 } & \multicolumn{2}{|c|}{ MM12 } & & 60 & HA & 27 \\
\hline & & & & & & & & & & & \\
\hline Allele & Freq. & Allele & Freq. & Allele & Freq. & Allele & Freq. & Allele & Freq. & Allele & Freq. \\
\hline 264 & 0.024 & 168 & 0.012 & 114 & 0.095 & 115 & 0.079 & 93 & 0.570 & 140 & 0.054 \\
\hline 268 & 0.369 & 176 & 0.012 & 120 & 0.052 & 117 & 0.016 & 97 & 0.117 & 142 & 0.054 \\
\hline 270 & 0.155 & 178 & 0.081 & 126 & 0.043 & 119 & 0.254 & 99 & 0.016 & 144 & 0.011 \\
\hline 272 & 0.429 & 180 & 0.407 & 128 & 0.095 & 123 & 0.048 & 103 & 0.227 & 148 & 0.630 \\
\hline 274 & 0.012 & 182 & 0.093 & 130 & 0.009 & 131 & 0.603 & 105 & 0.070 & 150 & 0.076 \\
\hline 276 & 0.012 & 184 & 0.395 & 132 & 0.431 & & & & & 154 & 0.174 \\
\hline & & & & 134 & 0.034 & & & & & & \\
\hline & & & & 136 & 0.216 & & & & & & \\
\hline & & & & 138 & 0.009 & & & & & & \\
\hline & & & & 144 & 0.017 & & & & & & \\
\hline$H_{\mathrm{O}}$ & 0.524 & $H_{\mathrm{O}}$ & 0.628 & $H_{\mathrm{O}}$ & 0.878 & $H_{\mathrm{O}}$ & 0.571 & $H_{\mathrm{O}}$ & 0.922 & $H_{\mathrm{o}}$ & 0.478 \\
\hline$H_{\mathrm{E}}$ & 0.655 & $H_{\mathrm{E}}$ & 0.663 & $H_{\mathrm{E}}$ & 0.744 & $H_{\mathrm{E}}$ & 0.563 & $H_{\mathrm{E}}$ & 0.850 & $H_{\mathrm{E}}$ & 0.561 \\
\hline $\mathrm{H}_{\mathrm{Eu}}^{\mathrm{E}}$ & 0.663 & $\mathrm{H}_{\mathrm{Eu}}^{\mathrm{E}}$ & 0.670 & $\mathrm{H}_{\mathrm{Eu}}^{\mathrm{E}}$ & 0.750 & $\mathrm{H}_{\mathrm{Eu}}^{\mathrm{E}}$ & 0.567 & $\mathrm{H}_{\mathrm{Eu}}^{\mathrm{E}}$ & 0.857 & $\mathrm{H}_{\mathrm{Eu}}^{\mathrm{E}}$ & 0.567 \\
\hline PIC & 0.590 & PIC & 0.600 & PIC & 0.780 & PIC & 0.510 & PIC & 0.600 & PIC & 0.530 \\
\hline $\mathrm{P}$ & 0.027 & $\mathrm{P}$ & 0.046 & $\mathrm{P}$ & 0.577 & $\mathrm{P}$ & 0.784 & $\mathrm{P}$ & 0.070 & $\mathrm{P}$ & 0.066 \\
\hline$F_{\text {IS }}$ & 0.212 & $F_{\text {IS }}$ & 0.064 & $F_{\text {IS }}$ & -0.104 & $F_{\text {IS }}$ & -0.007 & $F_{\text {IS }}$ & 0.051 & $F_{\text {IS }}$ & 0.157 \\
\hline & & & & ILS & & & & TG & 227 & & \\
\hline & & & & & & & & & & & \\
\hline Allele & Freq. & Allele & Freq. & Allele & Freq. & Allele & Freq. & Allele & Freq. & & \\
\hline 178 & 0.087 & 151 & 0.177 & 289 & 0.528 & 173 & 0.305 & 0.83 & 0.008 & & \\
\hline 184 & 0.043 & 153 & 0.008 & 291 & 0.120 & 175 & 0.161 & 0.85 & 0.190 & & \\
\hline 188 & 0.196 & 159 & 0.234 & 293 & 0.028 & 181 & 0.534 & 0.89 & 0.135 & & \\
\hline 192 & 0.674 & 161 & 0.161 & 295 & 0.111 & & & 0.91 & 0.056 & & \\
\hline & & 163 & 0.129 & 297 & 0.213 & & & 0.93 & 0.365 & & \\
\hline & & 165 & 0.290 & & & & & 0.95 & 0.206 & & \\
\hline & & & & & & & & 0.97 & 0.008 & & \\
\hline & & & & & & & & 0.99 & 0.032 & & \\
\hline$H_{\mathrm{O}}$ & 0.478 & $H_{\mathrm{O}}$ & 0.823 & $H_{\mathrm{O}}$ & 0.630 & $H_{\mathrm{O}}$ & 0.509 & $H_{\mathrm{O}}$ & 0.778 & & \\
\hline$H_{\mathrm{E}}$ & 0.498 & $H_{\mathrm{E}}$ & 0.787 & $H_{\mathrm{E}}$ & 0.649 & $H_{\mathrm{E}}$ & 0.596 & $H_{\mathrm{E}}$ & 0.765 & & \\
\hline $\mathrm{H}_{\mathrm{Eu}}$ & 0.504 & $\mathrm{H}_{\mathrm{Eu}}$ & 0.793 & $\mathrm{H}_{\mathrm{Eu}}$ & 0.655 & $\mathrm{H}_{\mathrm{Eu}}$ & 0.601 & $\mathrm{H}_{\mathrm{Eu}}$ & 0.772 & & \\
\hline PIC & 0.450 & PIC & 0.750 & PIC & 0.600 & PIC & 0.520 & PIC & 0.730 & & \\
\hline $\mathrm{P}$ & 0.491 & $\mathrm{P}$ & 0.938 & $\mathrm{P}$ & 0.540 & $\mathrm{P}$ & 0.168 & $\mathrm{P}$ & 0.004 & & \\
\hline$F_{\text {IS }}$ & 0.051 & $F_{\text {IS }}$ & -0.037 & $F_{\text {IS }}$ & 0.038 & $F_{\text {IS }}$ & 0.155 & $F_{\text {IS }}$ & -0.008 & & \\
\hline
\end{tabular}

Marker name, sample size $(\mathrm{N})$, alleles detected (allele) and their frequencies (freq.), observed $\left(H_{\mathrm{O}}\right)$, expected $\left(H_{\mathrm{E}}\right)$ and expected unbiased $\left(\mathrm{H}_{\mathrm{Eu}}\right)$ heterozygosities, polymorphic information content (PIC), P value of Hardy-Weinberg exact test (P), and $F_{\text {IS }}$ statistics. P values less than 0.05 (in bold) indicate significant deviations from equilibrium proportions. 
Table 2. Mean values for the entire sample.

\begin{tabular}{lcccc}
\hline$N_{\mathrm{A}}$ & $H_{\mathrm{O}}$ & $H_{\mathrm{E}}$ & $\mathrm{H}_{\mathrm{Eu}}$ & $F_{\text {Is }}$ \\
\hline 5.590 & 0.652 & 0.664 & 0.670 & 0.037 \\
\hline
\end{tabular}

Number of alleles $\left(N_{\mathrm{A}}\right)$, observed $\left(H_{\mathrm{O}}\right)$, expected $\left(H_{\mathrm{E}}\right)$ and expected unbiased $\left(\mathrm{He}_{\mathrm{u}}\right)$ heterozygosities, and $F_{\text {IS }}$ global index.

\begin{tabular}{|c|c|c|c|c|}
\hline Test/model & IAM & $\mathrm{P}$ & SMM & $P$ \\
\hline Sign test (expected/observed loci with heterozygosity excess) & $9.82 / 15$ & 0.008 & $10.03 / 9$ & 0.391 \\
\hline Standardized differences test (T2 values) & 3.138 & 0.0009 & -0.173 & 0.431 \\
\hline Wilcoxon test (probability - one-tail for heterozygosity excess) & & 0.00007 & & 0.391 \\
\hline
\end{tabular}

IAM = infinite allele model; SMM = stepwise mutation model.

\section{Mitochondrial DNA}

The hypervariable D-loop sequences of the 28 Uruguayan Creole calves were aligned with the B. taurus (Eucons) reference sequences. Gaps were completely removed, leaving 240 nucleotides (16023-16262 of the reference sequence).

The haplotypes used for the phylogenetic analysis were named according to Miretti et al. (2004), as follows: T1: African-derived haplogroup found in the Americas (AA1, AA3, AA5, and AA7), T3: European taurine haplogroup (Bar2, Pre2, Pre5, EA10, EA11, EA18, Her12, Jer24, and Arq5) and T (Her20). Eucons and Afcons sequences were also included in the analysis (Figure 2).

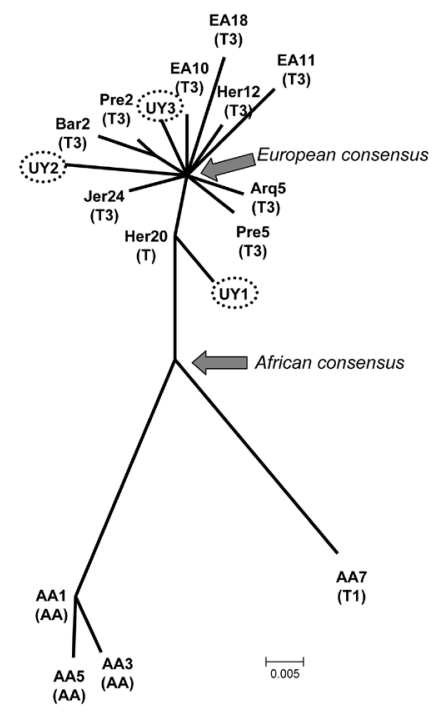

Figure 2. Maximum likelihood inference of the phylogenetic relationships of Uruguayan haplotypes and the mtDNA haplotypes described by Miretti et al. (2004). Uruguayan haplotypes, UY1, UY2 and UY 3 are indicated with punctuated circles. African-derived haplogroup found in America (AA) and European taurine haplogroup (T3 and T) are included in the tree next to the haplotype code, within parentheses. Haplotypes Her20 and AA1 show no distance from the respective closest node. Nodes indicated with gray arrows represent both consensus: European and African sequences. 
Three haplotypes were found after the analysis of the 28 nucleotide sequences of the D-loop region that belong to the European matriline group. They were named UY1, UY2 and UY3. The estimated mean number of pairwise nucleotide differences between haplotypes in the population was 1929 substitutions per site, while the mean nucleotide diversity was 0.008 ("p-distance"). Five polymorphic sites were found in the alignments, with an estimated haplotype diversity of 0.532 .

We estimated $F_{\mathrm{ST}}$ and the corrected average pairwise differences for the Uruguayan population with different geographic regions, namely Colombia, the Caribbean, Argentina and Bolivia, Brazil, the Iberian Peninsula (Spain and Portugal), Britain, Mainland Europe (excluding Iberian Peninsula), Western-Fringe Europe, and Africa (Table 4).

\begin{tabular}{|c|c|c|c|c|}
\hline & Geographic region* & No. sequences & $F_{\mathrm{ST}}$ & Corrected average pairwise difference \\
\hline \multirow{4}{*}{ America } & Colombia & 110 & 0.174 & 0.554 \\
\hline & Caribbean & 59 & 0.191 & 0.757 \\
\hline & Argentina and Bolivia & 40 & 0.243 & 0.698 \\
\hline & Brazil & 44 & 0.277 & 1.104 \\
\hline \multirow[t]{5}{*}{ Europe and Africa } & Iberian Peninsula & 214 & 0.290 & 0.875 \\
\hline & Britain & 78 & 0.297 & 0.946 \\
\hline & Africa & 110 & 0.353 & 1.904 \\
\hline & Mainland Europe (excluding Iberian Peninsula) & 117 & 0.359 & 0.959 \\
\hline & Western-Fringe Europe & 51 & 0.432 & 1.044 \\
\hline
\end{tabular}

*Geographic regions were adapted from Troy et al., 2001.

\section{DISCUSSION}

\section{Microsatellites}

Markers BM2113, CSSM66, INRA37, HEL9, and TGLA227 were very informative in this study due to their high polymorphism, heterozygosity and PIC, similar to what was previously found in a sample of breeding bulls with these same microsatellites (Armstrong et al., 2006a). These markers could be considered suitable for an efficient tool in the genetic management of this population, since its feral condition makes it difficult for a more thorough genealogical control (Delgado et al., 2012).

Random mating through many generations may account for the general situation of HWE observed. However, the low number of males with respect to the females affects effective population size $\left(N_{\mathrm{E}}\right)$ and $F_{\text {IS }}$ index. Stochastic events such as founder effect and genetic drift, acting since the origin of this population, may have affected allelic frequencies and may be the cause of the observed departures from equilibrium (Lirón et al., 2006; Egito et al., 2007; Martín-Burriel et al., 2011). Similar effects caused by similar circumstances were observed by Kantanen et al. (2000) in Eastern Finnish cattle.

Low $F_{\text {IS }}$ indices were in agreement with the equilibrium situation observed in the majority of the markers and showed that the overall degree of inbreeding was low, in accordance with the high level of diversity observed. This finding indicates that inbreeding would not be a probable cause in the few observed cases of Hardy-Weinberg disequilibrium, in spite of being common in small closed populations. The current reserve was created from 35 animals 
that came from different parts of the country, remnants of a huge ancestral population, and the fusion of small previously isolated populations probably increased $F_{\text {IS }}$ and heterozygosity of some of the markers (Hartl, 1988). The global heterozygosity level of the population measured with these nuclear hypervariable markers was moderately high (Table 2).

Several studies on other American Creole and Iberian cattle breeds using microsatellites from the same FAO and ISAG reference lists show important similarities with the results of the Uruguayan Creole cattle. In the Argentinean Creole cattle from Patagonia, Martínez et al. (2005b) found an $H_{\mathrm{E}}$ per locus of 0.18 to 0.80 . For a set of 9 microsatellites, Lirón et al. (2006) found $H_{\mathrm{E}}$ indices between 0.74 and 0.78 in 4 Creole breeds (Argentinean Creole and Yacumeño, Chaqueño and Saavedreño from Bolivia), where these breeds showed a higher genetic diversity than the British commercial breeds analyzed and were in HWE for most markers. In the Creole cattle of southern Brazil, Steigleder et al. (2004) found an $H_{\mathrm{E}}$ between 0 and 0.89 with a set of 14 microsatellites. Egito et al. (2007) found an $H_{\mathrm{E}}$ between 0.72 and 0.78 and mean $F_{\text {IS }}$ values between 0.05 and 0.09 , with a set of 22 microsatellite markers in 5 Brazilian Creole breeds (Caracu, Crioulo Lageano, Mocho Nacional, Pantaneiro, and Curraleiro, all B. taurus breeds of Iberian origin). The mean $N_{\mathrm{E}}$ per marker of these Brazilian Creoles was between 7.8 and 9.0, displaying a higher allelic richness than selected B. taurus and Zebu breeds of Brazil. The Mostrenca cattle breed from Andalusia (Spain), a proposed ancestral breed of the American Creole cattle, showed heterozygosity values between 0.29 and 0.77 (Martínez et al., 2005a). Barrera et al. (2006) found an average heterozygosity of 0.70 in 6 Creole cattle breeds of Colombia. In 2 Creole breeds from Panama, Villalobos Cortés et al. (2010) found heterozygosity indices ranging from 0.63 to 0.72 , and a global $F_{\text {IS }}$ of 0.041 . In a study of 40 Spanish and Portuguese breeds with 19 microsatellite markers, Martín-Burriel et al. (2011) found values of unbiased expected heterozygosity that ranged from 0.60 to 0.79 . Recently, using the same markers used here, a separate and distinctive cluster was reported for the most southern breeds of South America: Brazilian Caracu, Argentinean Creole, Argentinean Creole cattle from Patagonia, Uruguayan Creole, and Pampa Chaqueño from Paraguay, which are rather distant from other American populations (Delgado et al., 2012). These authors suggested a close genetic relationship between populations from nearby geographical regions and their findings support the genetic distinctiveness of the Uruguayan Creole cattle.

Bottleneck analysis did not reveal a clear pattern (Table 3). According to the IAM, 15 of the 17 microsatellites showed heterozygosity excess, supporting the hypothesis of population expansion after a recent bottleneck. T2 statistics and the Wilcoxon test agreed with this statement. However, under the SMM assumptions, none of the analyses suggested this. The Lshaped distribution of the mode-shift indicator (data not shown), expected under the mutationdrift equilibrium, also supported the idea that the population had not undergone a bottleneck in the recent past.

The origin of the population from only 35 individuals and its subsequent expansion could be considered a bottleneck event, although the time elapsed since then (70 years) may be long enough for the dilution of its effects. Moreover, random sampling of individuals may have included related animals of different generations, which may have reduced heterozygosity estimates and masked the effects of possible bottlenecks (Cornuet and Luikart, 1996; Kantanen et al., 2000). On the other hand, HWE analysis and $F_{\text {IS }}$ statistics do not support the existence of a population bottleneck in the recent past. The low number of breeding males employed for several generations could have reduced $N_{\mathrm{E}}$ and genetic diversity, causing bottle- 
neck-like effects. Both models are commonly used to explain microsatellite evolution: IAM is simple and more appropriate for dinucleotidic markers, as the ones used here, although it tends to overestimate the values; the SMM is more conservative and usually generates lower heterozygosity indices (Cornuet and Luikart, 1996; Villalobos Cortés et al., 2010). In conclusion, a possible bottleneck when this population was founded cannot be discarded, but other factors have probably affected this herd and must be taken into consideration for its future management.

\section{Mitochondrial DNA}

Haplotype UY1 $(\mathrm{N}=18)$ showed two changes from the Eucons sequence (139T, $255 \mathrm{C}$ ) and three changes from the Afcons sequence (139T, 113T, 50C). This was the most frequent haplotype (64\%) found in our population. Phylogenetic reconstruction suggested that UY1 derived from the European taurine haplogroup T (255C, Eucons) (Troy et al., 2001; Her20 sequence in Miretti et al., 2004). Haplotype UY2 $(\mathrm{N}=7)$ showed two changes with respect to Eucons (113C and 119C) and represented $25 \%$ of the sampled individuals. The less common haplotype found, named UY3 $(\mathrm{N}=3)$, showed a change in position 55 of the Dloop with respect to European consensus (55C). This last haplotype is exclusive of Uruguay in South America, and was previously found only in the Portuguese Maronesa and Barrosa breeds (Ginja et al., 2010).

Interestingly, the most frequent haplotype found in Uruguayan Creole cattle belonged to the relatively minor haplogroup $\mathrm{T}$, which represents an unusual situation compared to other cattle populations studied so far.

The median-joining network including all South American haplotypes except from Brazil also supported the proposed phylogenetic framework for these haplotypes. The inferred network showed no inconsistencies, except a position of a branch with two non-Uruguayan haplotypes, which are unexpectedly situated within the African group (Figure S1).

Our results suggest that the mtDNA genetic diversity of this population is rather low compared to other cattle populations, but not the lowest, as suggested by other studies (CarvajalCarmona et al., 2003; Ginja et al., 2010). Although highly informative, comparison of the results between populations is rather approximate, mainly due to differences in sampling procedures.

$F_{\mathrm{ST}}$ index estimations and corrected average pairwise differences suggested that Uruguayan population has been genetically isolated from other populations, which would indicate that it corresponds to a single genetic entity separate from other Creole cattle groups. This finding is supported by the recent analysis using microsatellites on a wide range of American cattle breeds mentioned above (Delgado et al., 2012). As expected, results with mtDNA also showed that Uruguayan population is genetically closer to South American than to other populations, although within South America, it was found to be closer to Colombian and Caribbean breeds than to the geographically closer Argentinean, Bolivian and Brazilian ones. A close inspection of the haplotypes analyzed showed that the Uruguayan population shares all haplotypes with Portuguese breeds in a distinctive pattern.

The most frequent haplotype, UY1, is also found in breeds of Portugal (Alentejana and Mertolenga), Mexico (Chihuahua Creole), Bolivia (Chusco Creole and Saavedreno Creole), and Argentina (Argentine Creole). On the other hand, UY2 is shared with Argentinean (belonging to Hereford, Aberdeen Angus and Argentine Creole), Bolivian (Yacumeno Creole), Brazilian (Curraleiro and Pantaneiro), Paraguayan (Pampa Chaqueno Creole), and Portuguese 
individuals (Friesian and Ramo Grande). Finally, UY3 is only shared with individuals that belong to Portuguese breeds (Maronesa and Barrosa) (Table S2). These observations could explain why the Uruguayan population is closer to Portuguese than Spanish breeds (data not shown). At the same time, it may also explain the genetic closeness to Caribbean and Colombian populations. Note that UY1, 2 and 3 may also be found outside America, Africa or Europe. For instance, UY3 was found in two Asian populations (Iraq and China), but the analysis of these results is beyond the scope of this paper, so we will not discuss this further.

The effective population size of the mitochondrial genome, as well as the intrinsic characteristics of both types of markers, could explain the observed differences between the estimated diversity indices derived from nuclear and mtDNA markers. On one hand, the Uruguayan Creole cattle were developed from the admixture of many Iberian breeds, a process that generates high levels of genetic diversity. On the other hand, population reduction over time, a possible bottleneck event 70 years ago, and the effects of genetic drift could be the cause of the loss of variability shown by the hypervariable D-loop analysis. The dispersal of the Creole populations towards the southern boundary of the territories occupied by cattle after its introduction on the American continent should also be taken into consideration. Molecular data from recent studies with microsatellites and mitochondrial DNA in American Creole and Iberian breeds support the common origin of almost all Creole cattle breeds in the former Spanish and Portuguese colonies (Carvajal-Carmona et al., 2003; Miretti et al., 2004; Lirón et al., 2006; Ginja et al., 2010; Delgado et al., 2012). These facts, together with the demographic structure of the Uruguayan Creole cattle population (Armstrong et al., 2006b), are key factors for the future development and management of this population.

\section{CONCLUSIONS}

A comprehensive molecular characterization of the Uruguayan Creole cattle population was achieved using nuclear and mitochondrial markers. While microsatellites showed high polymorphism and suggest medium to high genetic diversity, mitochondrial sequences suggest rather low diversity, probably due to differences in the sampling methods of both kinds of markers. The results were in agreement with previous studies in this and other American Creole breeds, and reinforce the genetic distinctiveness of this population.

\section{ACKNOWLEDGMENTS}

Research supported by PEDECIBA, Facultad de Veterinaria and CSIC/UdelaR (Uruguay). The authors thank Jorge de los Santos for his help in mtDNA extraction and SEPAE for the Uruguayan Creole cattle samples.

\section{Supplementary material}

\section{REFERENCES}

Armstrong E, Postiglioni A, Martínez A, Rincón G, et al. (2006a). Microsatellite analysis of a sample of Uruguayan Creole bulls (Bos taurus). Genet. Mol. Biol. 29: 267-272.

Armstrong E, Postiglioni A and González S (2006b). Population viability analysis of the Uruguayan Creole cattle genetic reserve. AGRI 38: 19-33. 
Armstrong E, Peñagaricano F, Artigas R, De Soto L, et al. (2011). Marcadores moleculares asociados al veteado de la carne en bovinos Criollos uruguayos. Arch. Zootec. 60: 707-716.

Arredondo H (1958). Santa Teresa y San Miguel. La Restauración de Las Fortalezas. La Formación de Sus Parques. "El Siglo Ilustrado", Montevideo.

Bandelt HJ, Forster P and Rohl A (1999). Median-joining networks for inferring intraspecific phylogenies. Mol. Biol. Evol. 16: 37-48.

Barrera GP, Martínez R, Pérez JE, Polanco N, et al. (2006). Evaluación de la variabilidad genética en ganado Criollo Colombiano mediante 12 marcadores microsatélites. AGRI 38: 35-45.

Belkhir K, Borsa P, Chikhi L, Raufaste N, et al. (1996-2004). Genetix 4.05: Logiciel Sous Windows ${ }^{\mathrm{TM}}$ Pour La Génétique des Populations. Laboratoire Génome, Populations, Iteractions. University of Montpellier II, Montpellier.

Botstein D, White RL, Skolnick M and Davis RW (1980). Construction of a genetic linkage map in man using restriction fragment length polymorphisms. Am. J. Hum. Genet. 32: 314-331.

Bradley DG, MacHugh DE, Cunningham P and Loftus RT (1996). Mitochondrial diversity and the origins of African and European cattle. Proc. Natl. Acad. Sci. U. S. A. 93: 5131-5135.

Carvajal-Carmona LG, Bermudez N, Olivera-Angel M, Estrada L, et al. (2003). Abundant mtDNA diversity and ancestral admixture in Colombian criollo cattle (Bos taurus). Genetics 165: 1457-1463.

Cornuet JM and Luikart G (1996). Description and power analysis of two tests for detecting recent population bottlenecks from allele frequency data. Genetics 144: 2001-2014.

De Alba Martínez J (2011). El Libro de Los Bovinos Criollos de América. Biblioteca Básica Agricultura (BBA), Mexico.

Delgado JV, Martínez AM, Acosta A, Álvarez LA, et al. (2012). Genetic characterization of Latin-American Creole cattle using microsatellite markers. Anim. Genet. 43: 2-10.

Egito AA, Paiva SR, Albuquerque MS, Mariante AS, et al. (2007). Microsatellite based genetic diversity and relationships among ten Creole and commercial cattle breeds raised in Brazil. BMC Genet. 8: 83.

Excoffier L, Laval G and Schneider S (2005). Arlequin (version 3.0): An integrated software package for population genetics data analysis. Evol. Bioinform. Online 1: 47-50.

FAO (1999). Documento de Líneas Directrices para La Elaboración de Planes Nacionales de Gestión de Los Recursos Genéticos de Animales de Granja. Medida de La Diversidad de Los Animales Domésticos (MoDAD). Marcadores Microsatélites Recomendados. Available at [www.fao.org/dad-is]. Accessed September 15, 2004.

Ginja C, Penedo MC, Melucci L, Quiroz J, et al. (2010). Origins and genetic diversity of New World Creole cattle: inferences from mitochondrial and Y chromosome polymorphisms. Anim. Genet. 41: 128-141.

Guindon S and Gascuel O (2003). A simple, fast, and accurate algorithm to estimate large phylogenies by maximum likelihood. Syst. Biol. 52: 696-704.

Hall TA (1999). BioEdit: a user-friendly biological sequence alignment editor and analysis program for Windows 95/98/ NT. Nucleic Acids Symp. Series 41: 95-98.

Hartl DL (1988). A Primer of Population Genetics. Second edn. Sinauer Associates Inc., Sunderland.

Hasegawa M, Kishino H and Yano T (1985). Dating of the human-ape splitting by a molecular clock of mitochondrial DNA. J. Mol. Evol. 22: 160-174.

Kantanen J, Olsaker I, Holm LE, Lien S, et al. (2000). Genetic diversity and population structure of 20 North European cattle breeds. J. Hered. 91: 446-457.

Keane TM, Creevey CJ, Pentony MM, Naughton TJ, et al. (2006). Assessment of methods for amino acid matrix selection and their use on empirical data shows that ad hoc assumptions for choice of matrix are not justified. BMC Evol. Biol. 6: 29.

Kelly L, Nicolini P, D’Angelo M, Nimo A, et al. (2002). Polimorfismo del gen DRB3.2 en bovinos Criollos del Uruguay. Arch. Zootec. 52: 7-9.

Kumar S, Nei M, Dudley J and Dudley J (2008). MEGA: a biologist-centric software for evolutionary analysis of DNA and protein sequences. Brief. Bioinform. 9: 306.

Lirón JP, Peral-García P and Giovambattista G (2006). Genetic characterization of Argentine and Bolivian Creole cattle breeds assessed through microsatellites. J. Hered. 97: 331-339.

Luikart G, Allendorf FW, Cornuet JM and Sherwin WB (1998). Distortion of allele frequency distributions provides a test for recent population bottlenecks. J. Hered. 89: 238-247.

Martín-Burriel I, Rodellar C, Cañón J, Cortés O, et al. (2011). Genetic diversity, structure, and breed relationships in Iberian cattle. J. Anim. Sci. 89: 893-906.

Martínez AM, Calderón J, Camacho E, Rico C, et al. (2005a). Genetic characterisation of the Mostrenca cattle with microsatellites. Arch. Zootec. 54: 357-361.

Martínez RD, Fernández EN, Bróccoli AM, Martínez A, et al. (2005b). Genetic variability in the Argentinian Creole cattle of Patagonic origin. Arch. Zootec. 54: 415-421. 
Miretti MM, Pereira HA Jr, Poli MA, Contel EP, et al. (2002). African-derived mitochondria in South American native cattle breeds (Bos taurus): evidence of a new taurine mitochondrial lineage. J. Hered. 93: 323-330.

Miretti MM, Dunner S, Naves M, Contel EP, et al. (2004). Predominant African-derived mtDNA in Caribbean and Brazilian Creole cattle is also found in Spanish cattle (Bos taurus). J. Hered. 95: 450-453.

Postiglioni A, Rincón G, Kelly L, Llambí S, et al. (2002). Biodiversidad genética en bovinos Criollos del Uruguay. Análisis con marcadores moleculares. Arch. Zootec. 51: 195-202.

Primo AT (1992). El ganado bovino ibérico en las americas: 500 años después. Arch. Zootec. 41: 421-432.

Raymond $\mathrm{M}$ and Rousset $\mathrm{F}$ (1995). GENEPOP (version 1.2): population genetics software for exact tests and ecumenicism. J. Hered. 86: 248-249.

Rincón G, D’Angelo M, Gagliardi R, Kelly L, et al. (2000). Genomic polymorphism in Uruguayan Creole cattle using RAPD and microsatellite markers. Res. Vet. Sci. 69: 171-174.

Rincón G, Armstrong E and Postiglioni A (2006). Analysis of the population structure of Uruguayan Creole cattle as inferred from milk major gene polymorphisms. Genet. Mol. Biol. 29: 491-495.

Rodríguez M, Fernández G, Silveira C and Delgado JV (2001). Estudio étnico de los bovinos Criollos del Uruguay. I. Análisis Biométrico. Arch. Zootec. 50: 113-118.

Steigleder CS, Almeida EA and Weimer TA (2004). Genetic diversity of a Brazilian Creole cattle based on fourteen microsatellite loci. Arch. Zootec. 53: 3-11.

Thompson JD, Higgins DG and Gibson TJ (1994). CLUSTAL W: improving the sensitivity of progressive multiple sequence alignment through sequence weighting, position-specific gap penalties and weight matrix choice. Nucleic Acids Res. 22: 4673-4680.

Troy CS, MacHugh DE, Bailey JF, Magee DA, et al. (2001). Genetic evidence for Near-Eastern origins of European cattle. Nature 410: 1088-1091.

Villalobos Cortés A, Martinez Martinez A, Escobar C, Vega-Pla JL, et al. (2010). Study of genetic diversity of the Guaymi and Guabala bovine populations by means microsatellites. Liv. Sci. 131: 45-51.

Walsh PS, Metzger DA and Higuchi R (1991). Chelex 100 as a medium for simple extraction of DNA for PCR-based typing from forensic material. Biotechniques 10: 506-513. 